\title{
Konseling untuk mengurangi inferioritas pada pasien skizofrenia
}

\author{
Riski Januar Tri Harsari
}

\begin{abstract}
Schizophrenia is a thought disorder that is not interconnected, the presence of erroneous perceptions, flat affect, withdrawal from the social environment, and failed functioning of life. This study examines the effect of Adlerian counseling to reduce feelings of inferiority in Schizophrenic patients. The assessment method used in this study is interview, observation, psychological tests namely Graphics Test, SSCT, WWQ, TAT, and WAIS. The intervention was given using counseling with the Adler approach which consisted of nine sessions. The results of the intervention showed that the inferior subject could be reduced, which was indicated by no longer being ashamed to talk to women, being able to find an understanding that he had implemented the wrong lifestyle all this time. Subjects also become more active.
\end{abstract}

\section{Keywords}

Inferiority, Adlerian Counseling, schizophrenia

\section{Pendahuluan}

Skizofrenia merupakan gangguan psikologis yang menyerang jati diri seseorang, memutus hubungan antara pikiran dan perasaan serta adanya persepsi yang terganggu, penyakit mental serius yang diderita seumur hidup. Episode akut dari skizofrenia ditandai dengan waham, halusinasi, pikiran yang tidak logis, pembicaraan yang tidak koheren, dan perilaku yang aneh (Farreny et al., 2018; Zhu et al, 2008)

Skizofrenia sendiri memiliki dua gejala yaitu gejala positif dan gejala negatif. Gejala positif merupakan bentuk gejala yang ada pada individu yang abnormal yang ditandai seperti adanya delusi, halusinasi, dan kehilangan kontak dengan realita. Sedangkan gejala negatif adalah gejala yang ada pada individu yang normal yaitu berupa afek yang datar, penarikan diri dari lingkungan sosial, dan juga bicara yang kurang (Delvecchio et al., 2013; McGurk \& Mueser, 2004). Gejala negatif juga bisa berupa masalah dengan perhatiannya, pembelajaran dan memori, pemikiran tidak logis, serta adanya kebingungan (WilderWillis, 2002(@). Pada penderita skizofrenia sendiri belum ditemukan obat untuk menghilangkan penyakit ini, namun cukup banyak temuan cara untuk mengatasi skizofrenia ini yang sebagian besar telah kembali berfungsi ke kehidupan sosialnya setelah adanya onset pertama (Delvecchio et al., 2013).

Permasalahan utama yang dialami DU pada gangguannya yaitu DU merasa inferior dengan kondisi dirinya. Pernah mengalami putus sekolah, pernah dihina oleh wanita yang disukai, dan tidak mendapat ijin dari orang tua untuk bekerja membuat DU merasa tidak ada satupun yang dapat ia capai untuk menuju superior. Hal tersebut juga didukung oleh perilaku kekerasan yang kerap dilakukan ayahnya ketika DU membuat kesalahan. DU mendapat diagnosa skizofrenia pada usia 21 tahun dan mengalami relapse sebanyak 3 kali. Ketiga peristiwa relapse tersebut ia alami dalam jangka waktu yang berdekatan. DU berulang kali mengalami relapse akibat tidak adanya kegiatan dirumah, yang membuat ia akhirnya berkeliling rumah karena merasa jenuh. DU juga melakukan atraksi berjogedjoged dengan berkeliling kampung. Sifat DU yang pendiam dan tertututup serta kurangnya pendirian membuat ia sulit untuk menolak permintaan orang lain sehingga ia sangat mudah dipengaruhi. Hal lainya yaitu kurangnya dukungan dari orang tua membuat ia semakin mudah relapse.

Setelah berhenti dari sekolah, DU sama sekali tidak memiliki kegiatan. Kedua orang tuanya selalu berupaya melarang DU untuk bekerja dengan alasan pekerjaanpekerjaan yang dilakukan DU tidak mendapatkan penghasilan yang sesuai. Perasaan tertekan dari tidak adanya kegiatan yang bisa DU lakukan mulai membuat DU mengalami halusinasi auditori dengan mendengar suara bisikan untuk berkeliling memunguti sampah. Memunguti

\footnotetext{
${ }^{1}$ Universitas Muhammadiyah Malang
}

Korespondensi:

Riski Januar Tri Harsari, Direktorat Program Pascasarjana, Universitas Muhammadiyah Malang, Jl. Tlogomas 246 Malang, Indonesia Email: riskijanuarts.15@gmail.com 
sampah-sampah plastik ia kerjakan semata-mata untuk mendapatkan penghasilan. Namun hal tersebut mendapatkan larangan dari kedua orang tuanya yang merasa malu akan perilaku anaknya tersebut.

Semenjak saat itu kondisi DU semakin goyah dan semakin diperparah ketika ia mencoba menyatakan perasaannya kepada salah seorang wanita yang ia kagumi sejak lama. Mendapatkan perlakuan yang kurang baik membuat DU memandang rendah dirinya sendiri. Hingga ia berupaya mengalihkan perasaan inferiornya dengan mengkonsumsi obat batuk komik selama satu minggu berturut-turut. Akibat dari mengkonsumsi obat batuk tersebut, DU kerap tidur lebih lama dari biasanya.

Tidak memiliki kegiatan yang bisa ia banggakan pada orang-orang disekitarnya, membuat ia merasa dipandang sebelah mata oleh mereka. Sebagai seorang lelaki, DU memiliki keinginan untuk diakui bahwa ia memiliki kemampuan bekerja. Namun keinginan untuk mencapai superioritasnya tidak dapat ia wujudkan karena hambatan-hambatan yang diciptakan oleh lingkungan sekitarnya. Sehingga munculah perasaan inferior yang saat ini DU alami. DU berupaya melakukan kegiatan yang menarik perhatian orang-orang disekitarnya untuk mendapatkan pengakuan sebagai wujud dari pencapaian superiornya. Adler meyakini bahwa manusia lahir disertai dengan perasaan rendah diri. Individu yang menyadari eksistensinya dalam kehidupan sosial, menumbuhkan perasaan rendah diri akan perannya dalam lingkungan. Hal tersebut muncul dikarenakan ketidakmampuan individu tersebut meraih suatu pencapaian yang dapat dicapai oleh individu lain. Sehingga hal tersebut membuat perasaan inferior pada individu muncul ketika ia berusaha untuk menyaingi kemampuan individu lain (Miller \& Taylor, 2016). Stresor-stresor yang datang membuat kepribadian DU menjadi rentan dan membentuk perasaan inferior dalam dirinya. Keinginan DU untuk mencapai superior tidak mampu ia wujudkan sehingga mengembangkan gangguan patologis pada DU (Miller \& Taylor, 2016).

Pendekatan konseling Adlerian merupakan pendekatan yang bersifat humanis yang cocok digunakan pada kasuskasus yang memiliki tujuan penguatan atas individu, serta pemberian dukungan guna memberikan perubahan secara positif Pada kasus ini pemeriksa menekankan permasalahan untuk mengurangi perasaan inferior pada DU dengan menggunakan konseling yang dilakukan dalam beberapa sesi. Yang bertujuan membantu DU untuk keluar dari stresornya dan menjadi individu yang lebih percaya diri. Konseling ini juga bertujuan untuk menguatkan DU atas kemampuan yang ia miliki agar DU mampu menjalani kehidupan untuk mencapai superioritasnya.

\section{Metode Asesmen}

Metode asesmen yang digunakan adalah wawancara, observasi, dan tes psikologi. Wawancara dilakukan kepada DU, orang tua DU, dan juga dokter yang menangani DU dengan tujuan untuk memperoleh informasi secara mendalam yang berkaitan dengan riwayat permasalahan DU. Observasi dilakukan sebagai pemeriksaan status mental DU yang meliputi penampilan DU, perilaku, afek, gangguan perseptual, orientasi, dan kesadaran DU.

Tes psikologi yang digunakan mencakup tes kepribadian yaitu tes grafis (BAUM, HTP, dan DAP). Tes grafis dilakukan guna mengetahui kepribadian DU secara mendalam karena hal ini merupakan data dukungan dalam mengetahui permasalahan pada DU. Asesmen juga melibatkan tes klinis menggunakan Sack's Sentence Completion Test (SSCT), untuk mengungkap dinamika kepribadian, yang dapat menampakkan diri DU dalam hubungan interpersonal dan dalam interpretasi terhadap lingkungan.Wescler adult intelligence scale (WAIS) untuk mengetahui kapasitas intelektual DU sehingga dapat mempermudah pemilihan intervensi yang akan diberikan. Thematic Apperception Test (TAT), untuk mengungkap dinamika kepribadian dalam hubungan interpersonal, dorongan emosi, serta konflik pribadi yang dominan dalam diri DU.

\section{Presentasi Kasus}

Berdasarkan hasil wawancara dengan DU dan kedua orang tuanya, diketahui bahwa DU merupakan anak pertama dari tiga bersaudara. DU memiliki dua saudara perempuan yang masing-masing terpaut usia 5-10 tahun dengan DU. DU saat ini tinggal bersama kedua orang tuanya dan juga adik perempuannya yang paling kecil. Pada dasarnya DU merupakan anak yang ceria dan aktif bergaul namun ia kerap mendapat perlakuan yang kurang menyenangkan dari teman-temannya. Perlakuan tersebut berupa ejekan yang ia dapatkan setiap hari pada saat ia mengaji disalah satu masjid dekat rumahnya. Saat itu DU berusia 7 tahun, dan adanya peristiwa tersebut membuat DU berubah, DU menjadi lebih senang bermain sendiri. DU juga pernah mengalami tidak naik kelas ketika Sekolah Dasar sebanyak dua kali, yaitu pada saat kelas IV ke kelas V dan kelas $\mathrm{V}$ ke kelas VI. Peristiwa tersebut membuat DU merasa malu pada teman-temannya. DU juga kerap diejek karena kata-kata yang ia ucapkan terkadang sulit dimengerti orang-orang yang berada disekitarnya. Hal tersebut juga membuat ia kerap merasa malu ketika berbicara dengan orang, karena seringnya ditertawakan. Hal ini membuat ia semakin enggan bergaul dengan teman-teman lain, dan kerap bermain sendiri.

Sejak kecil DU lebih banyak menghabiskan waktunya bersama sang ibu dikarenakan ayah harus bekerja di luar kota. Kedekatan antara ibu dan DU membuat ibu sering merasa sangat khawatir sehingga ibu sering meminta DU untuk berada di rumah saja. Sejak kecil DU merasa tidak bebas, karena ibu selalu melarang-larang DU untuk bermain keluar rumah. Karena sikap DU yang sangat penurut, membuat ia merasa tertekan karena selalu mengikuti keinginan ibunya. Hal tersebut masih terjadi hingga DU tumbuh dewasa, ibunya masih kerap melarang DU bahkan untuk bekerja. Sejalan dengan hal tersebut 
hasil tes Grafis dan TAT yang menyatakan adanya perasaan tertekan pada DU namun ia berupaya untuk menerima keadaan.

DU merupakan anak yang paling dekat dengan orang tuanya, kedua orang tuanya juga begitu menyayangi DU. Hal-hal yang DU minta kepada orang tua akan dengan segera diberikan. Ayah DU juga menyatakan bahwa DU tidak pernah kekurangan, dibandingkan dengan teman-teman disekitarnya. Hal ini membuat DU mengembangkan sikap kurang mandiri dan selalu bergantung. Hal tersebut juga sesuai dengan hasil dari tes grafis DU yang menyatakan bahwa DU kerap bergantung dengan lingkungan sosialnya.

Meskipun DU pernah tinggal kelas saat disekolah dasar namun DU mampu menamatkan pendidikan Sekolah Dasarnya. Kemudian DU melanjutkan pendidikannya kesalah satu pondok pesantren di Kotanya. DU yang sedari kecil memiliki kemampuan mengaji ini memiliki keinginan untuk memperdalam kemampuannya di Pesantren. Namun hal tersebut hanya bertahan sampai dengan dua tahun, tepat ditahun kedua saat hendak diadakan tes kenaikan tingkat ia memilih untuk berhenti dan keluar dari pesantren. Hal tersebut bukan tanpa alasan, ia merasa tidak memiliki kemampuan untuk mengerjakan tes tersebut, sehingga DU memilih untuk berhenti.

Usai memilih keluar dari pondok pesantren DU tidak memiliki kegiatan apapun yang membuat ia merasa sangat jenuh karena harus berada didalam rumah terus menerus. DU memutuskan untuk menjadi nelayan, namun orang tuanya tidak memberikan persetujuan dengan pekerjaan yang ia pilih tersebut dengan alasan pekerjaannya terlalu berisiko.

Kemudian DU melanjutkan dengan berjualan farpum keliling namun juga tidak mendapat persetujuan orang tuanya dan akhirnya memilih untuk berhenti. Hal tersebut tentu tidak sejalan dengan keinginan DU. DU beranggapan bahwa sebagai anak laki-laki harus bekerja dan berpenghasilan, dengan begitu ia tidak perlu meminta uang kepada orang tuanya dan bisa sama dengan teman-teman seusianya. DU pun memiliki keinginan bahwa suatu saat ia bisa memiliki rumah, kendaraan pribadi, dan juga menikah dengan gadis yang ia cintai. Namun keinginan DU tersebut tidak dapat ia realisasikan sehingga memunculkan perasaan yang semakin tertekan. Permasalahan menjadi semakin kompleks, karena DU berupaya selalu menuruti keinginan orang tuanya, yang bertentangan dengan keinginan dalam dirinya. Ia cenderung tidak mampu mengambil sikap dan langkah untuk masa depannya. DU hanya menurut dan bergantung dengan kedua orang tuanya terutama pada sosok ibu.

Kondisi DU yang tidak memiliki pekerjaan membuat ia merasa tidak berharga sebagai seorang laki-laki. Kondisi lain yang juga mendukung yaitu ketika DU menyatakan perasaan cintanya kepada wanita yang ia kagumi. Namun cintanya ditolak dan DU mendapat cemooh dari wanita tersebut dengan kata-kata kasar seperti bodoh, jelek, dan gila. Wanita tersebut juga mengatakan bahwa DU tidak perlu menghubunginya lagi. Penolakan tersebut membuat DU merasa semakin inferior dengan dirinya. Hal ini mengakibatkan rasa rendah diri yang abnormal dimana suasana hati individu menjadi terbatas, dan membuat hidupnya semakin terasa sulit (Adler, 1964). DU yang berstatus tidak bekerja dan tidak berpenghasilan, serta merasa dirinya kurang memiliki wajah yang rupawan membuat dirinya begitu terluka. DU menganggap dirinya memiliki kelemahan fisik dan motivasi yang rendah sehinga memberikan stimulasi perasaan subjektif yaitu inferioritas (Adler, 1927).

Menurut penuturan orangtuanya, DU mulai mengalami kekacauan pikiran dan perasaan lima hari setelah hari Raya Idul Fitri 2019. DU tiba-tiba marah, dan sering berbicara sendiri, serta sering berkeliling rumah tanpa tujuan yang jelas. Hingga akhirnya gejala tersebut muncul dan sejak saat itu DU mulai sering tertawa sendiri tanpa sebab. Namun keluarga belum menyadari tentang kondisi yang di alami DU tersebut.DU menjadi semakin terombang-ambing dengan dirinya dan mengembangkan perasaan inferiornya. Keinginan DU untuk berjuang dalam mencapai superioritas dengan bekerja juga terhalang oleh orang tua yang kerap tidak merestui keinginannya. Perasaan sulit yang dirasakan membuat ia melarikan dirinya dengan menggunakan obat-obatan secara berlebih. DU mengkonsumsi obat batuk sebanyak 20 bungkus perhari, dan mengkonsumsi hal tersebut selama dua minggu. Usai mengkonsumsi hal tersebut DU merasa lebih rileks dan menjadi semakin percaya diri dihadapan orang lain. Permasalahan yang bertubi-tubi membuat dirinya menjadi tidak stabil. Ia sering berada dikamar dalam keadaan tidak sadarkan diri usai mengkonsumsi obat batuk tersebut.

DU juga semakin tidak terkendali karena tidak adanya aktivitas yang bisa ia kerjakan, ia hanya boleh berada dirumah tanpa adanya aktivitas apapun. Hal tersebut membuat DU mulai merasa jenuh hingga mulai mendengar bisikan untuk berkeliling kampung sembari memunguti rongsokan. Namun setiap hal tersebut dilakukan, DU akan mendapat kekerasan fisik dari ayahnya. Penilaian ayah mencari rongsokan adalah perilaku yang membuat malu nama keluarga. Meskipun DU mendapatkan limpahan kasih sayang, namun DU merasa tertekan dengan keadaan tersebut. Sikap orang tua yang kerap memanjakan membuat DU mengembangkan gaya hidup sebagai anak yang bergantung, tidak memiliki tujuan, serta konsep diri yang belum matang. Hal tersebut juga sesuai dengan hasil tes grafis DU yang menyatakan hal yang sama. DU menjadi sulit menentukan jalan hidupnya sendiri, dan cenderung mengikuti keinginan orang lain.

Pola asuh memanjakan membuat DU mengembangkan gaya hidup yang sangat bergantung dengan orang-orang disekitarnya termasuk dengan ibunya. Gaya hidup yang ada pada DU membuat DU memiliki motivasi yang rendah sehingga menumbuhkan perasaan tidak mampu dalam dirinya. Karateristik yang nampak pada gaya 
hidup manja adalah mudahnya merasa putus asa, sering merasa bimbang, sangat sensitif, tidak sabar, emosi yang berlebihan, dan munculnya kecemasan.

Perasaan tertekan, dan inferior yang DU alami semakin memperkuat simtom-simtom skizofrenia. Ketidaksesuaian antara pemikiran, imajinasi dan emosi dengan keadaan yang sebenarnya membuat DU sering berbicara melantur dan tertawa sendiri, serta munculnya delusi yaitu waham kebesaran yang mana DU mengaku sebagai seorang Syekh. Selain itu juga terdapat halusinasi auditorik seperti mendengar bisikan yang dikatakan berasal dari jin dan juga halusinasi visual dengan melihat pocong. Perilaku abnormal ini tumbuh dikarenakan DU tidak mampu mencapai superioritasnya guna meninggalkan inferioritasnya. Memiliki kelemahan fisik yaitu kesulitan berbicara dengan jelas membuat DU mengembangkan perasaan inferiornya. Perasaan inferiornya semakin jadi usai mendapat penolakan dan kecaman dari seorang wanita. DU memiliki keinginan untuk menjadi superior guna menunjukkan bahwa didalam diri DU terdapat sesuatu yang bermakna. Namun harapan masa depan akan hidup mandiri, memiliki rumah pribadi, kendaraan pribadi, dan menikah dipersepsi kabur oleh DU. Hal tersebut dikarenakan goalsnya tidak pernah mendapat persetujuan dari orang tuanya. Setiap pekerjaan yang DU lakukan, selalu dinilai negative oleh orang tuanya. Pikiran, perasaan, dan tindakan yang dilakukan oleh DU tidak bisa mengarah pada satu tujuan yang sama sehingga tidak mencapai tujuan yang diinginkan.

\section{Diagnosis dan Prognosis}

\section{Diagnosis}

Berdasarkan uraian kasus, hasil asesmen dan rujukan yang ada di Diagnostic and Statistical Manual of Mental Disorder Fifth Edition (DSM-V) (American Psychiatry Association, 2013), maka dapat ditegakkan diagnosis bahwa klien memenuhi kriteria diagnostik: kode 298.8 (F28) yakni Other Specified Schizophrenia Spectrum. DU sudah mengarah pada gangguan skizofrenia yang dialami klien saat ini memenuhi 4 dari 4 ciri dari Other Specified Schizophrenia Spectrum meliputi adanya halusinasi, delusi, adanya sindrom dengan gejala psikotik disertai dengan permasalahan inferioritas.

Berdasarkan data WHODAS menunjukkan bahwa DU berada dalam kategori sedang dengan kategori keberfungsiannya berada pada skor 3. Hal tersebut menunjukkan bahwa DU dapat cukup berfungsi atau dikatakan masih bisa melakukan aktivitas sehari-hari dengan cukup.

\section{Prognosis}

Berdasarkan hasil asesmen diketahui sikap keluarga cukup terbuka terhadap informasi mengenai kehidupan DU. Namun kondisi psikologis DU pada aspek sikap yang mudah menyerah, kemampuan intelegensi yang rendah, serta kurangnya faktor dukungan dari lingkungan keluarga, kurang mampu menjadi faktor pendukung dari kesembuhan DU. Sehingga dapat disimpulkan bahwa prognosis buruk.

\section{Intervensi}

Jenis intervensi yang digunakan dalam kasus ini menggunakan konseling. Konseling adalah perspektif konstruktivis relasional yang dapat berfungsi sebagai jembatan dialog yang berguna antara konstruktivis kognitif dan perspektif konstruktivis sosial (Watts, 2017). Konseling dengan pendekatan teori adler memberikan landasan teori yang kuat untuk konseling, dengan tujuan mendukung, mendorong, dan memberdayakan individu untuk perubahan positif (Tekinalp, 2017). Konseling Adlerian merupakan sebuah model pendekatan yang mengubah persepsi negatif seseorang menjadi pribadi yang bersifat positif (Carich, 2001). Teknik dalam proses konseling Adlerian adalah perubahan tidak hanya dalam berpikir dan berperilaku tetapi juga dalam menumbuhkan perasaan bagi masyarakat, dan sebagai cara hidup (Close, 2015).

Prinsip adler dianggap sebagai salah satu pendekatan konseling yang lebih komperhensif dalam bidang kesehatan mental (Miller \& Taylor, 2016). Target dari konseling yang diberikan adalah untuk mengurangi perasaan inferior yang dialami DU, dengan memberikan dorongan agar DU bisa hidup ditengah masyarakat sebagai anggota masyarakat yang sederajat. Oleh karena itu proses konseling berfokus pada penyediaan informasi, mengajar, membimbing dan menawarkan dorongan semangat kepada DU yang kehilangan semangat. Dorongan semangat merupakan metode yang paling kuat yang bisa disediakan untuk mengubah keyakinan seseorang. Dorongan tersebut mampu menolong DU dalam membangun rasa percaya diri dan menstimulasi keberanian. Keberanian yang dimaksudkan adalah kemauan untuk berbuat dengan cara-cara yang konsisten dengan kepentingan masyarakat.

Alasan pemilihan intervensi ini karena DU merasa inferior dengan kondisi dirinya, DU kehilangan semangat sehingga menyebabkan perilaku yang keliru dan kurang berfungsi. Oleh karenanya pemberian konseling Adlerian diharapkan mampu mengubah keyakinan DU sehingga mampu mengurangi perasaan inferiornya dan DU mampu berfungsi dalam kehidupan masyarakat sebagaimana seharusnya. Intervensi yang akan diberikan menyesuaikan kemampuan DU. Pemberian informasi juga diberikan dengan menggunakan bahasa yang lebih sederhana, guna memudahkan DU memahami maksud dan tujuan dari proses terapi. Intervensi ini dilakukan di RSJ Lawang yang diberikan dalam 10 sesi, yaitu:

Sesi 1: Psikoedukasi. Psikoedukasi diberikan kepada anggota keluarga DU. Tujuan dari psikoedukasi ini adalah menambah pemahaman mengenai kondisi DU serta pemberian dukungan sebagai untuk kesembuhan DU. Pada sesi ini disampaikan kepada orang tua DU mengenai 
kondisi DU tentang apa yang DU derita. Kemudian dilanjutkan dengan menginformasikan apa yang menjadi keinginan terbesar DU.

Sesi 2: Mempertahankan hubungan baik dengan klien. Pada sesi ini ditujukan untuk membuat DU paham bahwa permasalahan DU harus diselesaikan. Membangun hubungan yang hangat dengan mengedapankan empati. Praktikan menawarkan terapi pada DU sebagai solusi dan meminta ketersediaan DU. Pada sesi ini praktikan juga menjelaskan maksud dan tujuan dari terapi ini.

Sesi 3: Analisis. Tujuan dari tahap ini adalah untuk membuat pilihan gaya hidup yang lebih produktif untuk klien. Untuk langkah pertama mengajak DU untuk melakukan relaksasi. Hal ini dilakukan secara sederhana, mengingat kondisi DU. Relaksasi dilakukan dengan meminta DU menarik napas panjang dengan posisi duduk tenang, dan memberikan sugesti-sugesti positif kepada DU.

Tahapan selanjutnya dilakukan proses konfrontasi dengan bahasa yang sederhana praktikan mencoba mengajukan beberapa pertanyaan mengenai apa yang DU inginkan dalam kehidupannya. DU sempat menjelaskan bahwa ia ingin memiliki sebuah motor ninja dan menikah. Kemudian praktikan mencoba menanyakan dengan apa DU bisa memiliki itu jika tanpa pekerjaan. DU mengatakan bahwa dirinya bisa memiliki dengan meminta kepada orang tuanya. Setelah praktikan mencoba terus melakukan konfrontasi, DU pada akhirnya memahami bahwa segala sesuatu yang ia inginkan harus dengan memiliki pendapatan.

Praktikan melanjutkan dengan memberikan motivasi bahwa dengan kemampuan yang dimiliki DU, ia bisa menekuninya sebagai pekerjaan. DU mengatakan ingin berjualan nasi goreng. Selanjutnya DU diberikan masukan bahwa dengan memilih pekerjaan tersebut DU harus bisa bertanggung jawab. Selanjutnya praktikan menjelaskan dengan bahasa yang sederhana apa yang dimaksud bertanggung jawab, DU memahami maksud praktikan dengan menganggukkan kepala. Kemudian praktikan memberikan motivasi bahwa DU bisa bertanggung jawab dengan pilihannya. DU mengatakan bahwa dirinya ingin sembuh dan dengan itu DU harus melakukan aktivitas yang bermanfaat.

Sesi 4: Analisis dengan menggunakan teknik bertindak "seandainya". Tujuan dari tahapan ini adalah memahami gaya hidup DU, hal-hal yang mempengaruhi gaya hidup yang DU jalankan saat ini. Pada tahapan ini praktikan mencoba menanyakan tentang apa yang menjadi keinginan DU. DU kemudian menjawab bahwa keinginannya adalah bekerja. Kemudian dilanjutkan dengan melakukan pengandaian. Pada tahap pengandaian ini, praktikan mencoba menjelaskan dengan bahasa yang lebih sederhana. DU mengandaikan bahwa dirinya bisa bekerja diperusahaan dan mendapatkan penghasilan besar.
Sesi 5: Analisis dengan teknik "meludah di sup klien". Pada tahap ini memiliki tujuan untuk membuat perilaku DU tidak muncul kembali. Praktikan menjelaskan pada tahap ini bahwa hal yang membuat DU kambuh adalah tidak adanya aktivitas oleh karenanya dengan aktif beraktivitas secara positif dapat membantu DU untuk mengurangi berdiam diri yang akhirnya mempengaruhi pikiran kosong dan bisa membuat halusinasi DU bekerja lebih aktif.

Sesi 6: Insight dengan teknik "menangkap diri sendiri". Pada tahap ini memiliki tujuan agar DU dapat belajar memahami tingkah laku dan pemikiran yang merusak dirinya. Mengajarkan klien untuk bisa mengalahkan diri sendiri dengan memberikan motivasi dan menjelaskan konsekuensi dari perilaku sebelumnya. Praktikan menjelaskan perasaan inferior DU muncul dan menjadikan DU seperti saat ini. Hal tersebut terjadi karena DU merasa tidak ada yang bisa ia banggakan dengan dirinya.

DU kembali diberikan motivasi bahwa DU bisa melakukan aktivitas merawat ayam menjadi bagian dari pekerjaan yang bisa menghasilkan pendapatan. Praktikan menegaskan bahwa ketika melakukan suatu pekerjaan DU harus bisa bertanggung jawab dan serius dengan apa yang ia kerjakan. DU menyetujui dengan tersenyum dan menganggukkan kepala.

Sesi 7: Reorientation dengan teknik penetapan tugas. Tahapan ini memiliki tujuan untuk membantu DU menetapkan tujuan yang mudah dicapai dimulai dengan capaian jangka pendek dan kemudian dilanjutkan dengan jangka panjang. Hal yang dilakukan adalah membuat kesepakatan dan jadwal kegiatan yang bisa DU lakukan sebagai bentuk latihan jangka pendek. DU dan praktikan bersama menyepakati macam-macam kegiatan baik untuk jangka panjang maupun juga jangka pendek yang bisa DU lakukan selama di rumah sakit dan dirumah setiap harinya. DU menyetujui dengan dibantu praktikan untuk menyepakati kegiatan-kegiatan yang akan dia kerjakan.

Sesi 8: Reorientation dengan teknik tekan tombol. Pada tahapan ini bertujuan untuk membantu DU agar memiliki kegiatan dan tujuan dalam hidupnya. DU diberikan motivasi agar DU menyadari bahwa DU memiliki pilihan yaitu melakukan aktivitas. Ini bertujuan untuk membantu mengubah gaya hidupnya yang salah selama ini. Dengan meningkatkan self awareness DU, maka gaya hidup dan cara berperilaku DU bisa sesuai dengan pola kehidupan. DU akan direedukasi oleh praktikan seperti membentuk DU menjadi pribadi yang baru. Pada tahap ini DU mampu mengikuti serangkaian kegiatan yang sudah dijalankan, meskipun pada awal kegiatan DU masih dibantu oleh praktikan untuk mengingatkan. Namun harihari berikutnya DU sudah bisa melakukan aktivitas jangka pendeknya sendiri tanpa perlu diingatkan oleh praktikan.

Sesi 9: Terminasi. Tahapan ini diisi dengan mengapresiasi dan memotivasi DU agar tetap melaksanakan tugas harian tanpa bantuan praktikan. Membahas pencapaian 
DU setelah 14 hari melakukan kegiatan intervensi jangka pendek bersama. Selama masa terminasi DU mengatakan bahwa ia sangat tidak sabar dijemput pulang. Ia mengatakan bahwa selama ini ia sudah mengikuti kegiatan meskipun tanpa diperintah. DU juga tampak lebih aktif dalam ruangan dengan banyak membantu pekerjaan perawat, seperti memberikan makanan kepada teman-teman ruangan, mencuci piring, ataupun membersihkan ruangan.

Sesi 10: Follow up. Pada saat follow up orang tua menyatakan bahwa kondisi DU sudah cukup baik, dengan banyak berkegiatan. Orang tua juga sudah mendaftarkan DU kepada tetangganya untuk bekerja. Namun orang tua mengatakan bahwa mereka tidak sanggup merawat DU karena DU masih sering tidak tidur dan berkeliling dirumah sehingga orang tua kembali membawa DU ke Rumah Sakit Jiwa Lawang.

\section{Hasil dan Pembahasan}

\section{Hasil}

Sebelum berlangsungnya proses konseling yang dilakukan pada DU, praktikan berupaya melakukan psikoedukasi kepada keluarga DU. Psikoedukasi dilakukan di rumah DU kepada anggota keluarga DU yang terdiri dari ayah, ibu, dan adik DU. Hasil dari psikoedukasi orang tua DU mulai terbuka dan memahami bahwa keinginan anaknya adalah bekerja. Orang tua segera berupaya mencarikan pekerjaan untuk DU dan berupaya untuk mendukung DU. Kunjungan berikutnya praktikan juga menyampaikan bahwa orang tua bisa berupaya membantu mencegah DU untuk relapse dengan turut berpartisipasi mendukung DU untuk melaksanakan kegiatan yang sudah diajarkan praktikan. Orang tua memahami dan mau untuk terlibat aktif dalam mendukung dan mengawasi kegiatan DU selama dirumah.

Target pada intervensi yang diberikan kepada DU sendiri adalah DU dapat mengurangi perasaan inferiornya dengan cara mengubah gaya hidupnya. Mengubah gaya hidup dimulai dari mengajarkan bagaimana hidup seharusnya. DU yang semula takut dan tidak percaya diri melakukan komunikasi terutama dengan perempuan, kini mau melakukan komunikasi dengan perempuan. DU juga terlihat mau mengajak orang yang ada disekitarnya untuk berbicara bahkan merespon pembicaraan, yang dilakukan oleh perawat dan praktikan lain yang ada di ruangan bangsal.

DU semula meyakini bahwa dirinya tidak hebat karena ia memahami bahwa orang-orang yang bekerja diperusahaan dan berpendapatan besar adalah orang-orang yang hebat. Namun kini ia memahami bahwa hal tersebut harus disesuaikan dengan kemampuan masing-masing. DU juga menyadari bahwa kemampuannya adalah merawat ayam, dan berjualan. Sehingga hal tersebut bisa ia lakukan untuk mendapatkan penghasilan. DU baru menyadari bahwa kemampuannya memelihara hewan mampu ia jadikan sebagai ladang penghasilan untuknya. Sehingga
DU memutuskan untuk memelihara ayam untuk di ternak, hal tersebut disepakati dihadapan praktikan. Ayam dipilih karena tidak terlalu memakan biaya besar dan cukup mudah perawatannya. Hal tersebut cukup mudah DU lakukan mengingat DU pernah memelihara hewan ternak sebelumnya, sehingga cukup mudah bagi DU untuk belajar hal apa saja yang harus ia lakukan. Dengan menemukan potensi yang DU miliki, maka hal ini mampu membantu DU untuk mengurangi perasaan inferioritasnya. Apalagi sebelumnya pekerjaanlah yang menjadikan DU merasa minder terhadap perempuan, dan juga terhadap rekanrekan seusianya.

Sebelumnya DU juga merasa bahwa tidak ada yang bisa ia banggakan dirinya, karena tidak ada yang bisa ia lakukan. Ia benar-benar merasa inferior dengan kondisi dirinya yang tidak memiliki pekerjaan. Namun kini setelah dilakukannya konseling DU menjadi sadar bahwa merawat ayam juga bagian dari bekerja. Sehingga DU tidak perlu merasa malu lagi. Perubahan yang tampak pada DU saat DU mulai memahami persepsi yang salah mengenai kondisinya, bahwa ia merasa tidak memiliki kemampuan apapun. DU tidak menyadari selama ini bahwa dirinya memiliki kemampuan merawat ayam yang sudah ia miliki sejak ia kecil. Setelah praktikan membantu DU dalam menemukan kemampuan yang DU miliki, DU menjadi cukup bersemangat untuk melakukannya lagi.

Hasil keseluruhan sampai dengan proses terminasi banyak ditemukan perubahan oleh DU. Terutama 2 minggu pertama selama berada di rumah sakit jiwa lawing. DU cukup banyak melakukan perubahan. Seperti target-target dari terapi dalam sesi re-orientation dan re-education dimana DU seperti diatur ulang, diajarkan bagaimana menjalankan aktivitas agar perasaan inferioritas yang dimiliki sebelumnya tidak kembali lagi. Keseluruhan dapat berjalan dengan baik, meskipun pada tahap akhir sebelum terminasi DU mengalami ketidakstabilan dalam menjalankan aktivitas jangka panjangnya dengan adanya penurunan. Namun secara keseluruhan dapat terselesaikan hingga terminasi. Penggunaan bahasa yang sederhana diberikan pada setiap sesinya dan kertas adalah media yang membantu DU untuk memahami apa yang akan terjadi pada dirinya. Menggunakan media kertas rasanya cukup membantu memberikan insight DU akan kondisi dirinya, dan ia menyadari bahwa dirinya membutuhkan perubahan agar ia bisa hidup menjadi lebih baik dari keadaan sebelumnya.

Pada saat dilakukan follow up, praktikan tidak dapat menemui DU dikarenakan DU dibawa kembali oleh orang tuanya sehari sebelum praktikan datang. Namun saat ditanya bagaimana perkembangan DU sejauh ini, orang tua mengatakan bahwa usai intervensi berakhir DU masih bisa menjalani aktivitas seperti yang sebelumnya dilakukan dengan cukup baik. Orang tua juga sempat senang akan hal tersebut. Namun hari berikutnya DU dibawa kembali ke rumah sakit. Orang tua beralasan dibawanya kembali DU ke rumah sakit dikarenakan DU membuat ulah dengan menjatuhkan motor milik tetangganya saat ia berkunjung 
ke masjid didekat rumahnya. Orang tua yang menerima complain dari orang yang bersangkutan, merasa tidak sanggup lagi dengan kondisi DU yang demikian. Sehingga orang tua memutuskan kembali untuk menitipkan anaknya di rumah sakit jiwa.

Namun saat praktikan mencoba mencari informasi tentang DU kepada tetangga dekatnya. Orang tersebut mengatakan bahwa semalaman DU mendapatkan kekerasan fisik oleh ayahnya usai menjatuhkan motor tetangganya. DU dipukuli hingga terdengar suara DU meminta tolong karena kesakitan. Tetangga juga mengatakan bahwa DU sempat dipukul dengan menggunakan sandal jepit dan ikat pinggang dikepalanya berkali-kali. Ibu DU hanya menangis dan pasrah, tak selang beberapa lama ayah DU dan dua orang paman DU membawa DU kembali ke Rumah Sakit Jiwa Lawang.

\section{Pembahasan}

Pemberian psikoedukasi yang dilakukan kepada keluarga DU cukup membawa peruabahan pemahaman pada keluarga mengenai anggota keluarga dengan skizofrenia. Keluarga yang semula kurang memahami apa yang menjadi penyebab DU mengalami gangguan kejiwaan, serta langkah apa yang harus dilakukan untuk membuat DU bisa lebih baik dari sebelumnya bisa dipahami setelah dilakukannya sesi psikoedukasi. Sesuai dengan hal tersebut bahwa psikoedukasi telah banyak memberikan keberhasilan dalam mendidik, membantu keluarga dalam mengembangkan sumber dukungan sosial, serta mampu mengembangkan keterampilan coping. Selain pemberian psikoedukasi keberadaan praktikan di sana juga untuk memberikan dorongan dan dukungan kepada anggota keluarga. Praktikan juga memberikan penguatan agar para anggota bisa saling bekerja dan saling menguatkan satu sama lain dalam merawat DU.

Keinginan DU yang selalu dipenuhi membuat dirinya sulit untuk membuat keputusan secara mandiri. DU menjadi sangat penurut dan memiliki sikap ketergantungan pada sosok orang tuanya. DU merasa selalu mendapat perlindungan serta kebutuhan yang selalu terpenuhi, sehingga DU mengembangkan sikap yang penuh dengan kebimbangan, mudah putus asa yang berlebihan, sensitif berlebihan, tidak sabar, emosi yang berlebihan, dan juga mudah cemas (Adler, 1927).

Kesulitan DU dalam membuat keputusan sendiri membuat DU cenderung selalu mengikuti keinginan orang tuanya termasuk untuk urusan bekerja. Untuk itu DU mulai mencari jalan lain menuju superioritasnya dengan kerap memunguti rongsokan dan menjualnya. Namun DU malah mendapatkan kekerasan fisik akibat dari perilaku yang ia lakukan tersebut. Pandangan adler ketika individu mendapat pengalaman yang bersifat negatif menjadikan individu tersebut semakin meningkatkan perasaan inferiornya (Akdogan et al., 2018).

Hasil intervensi yang dilakukan kepada DU membawa banyak dampak positif dalam gaya hidup DU. Hal tersebut dapat terlihat dari banyaknya perubahan yang ada pada diri DU yang jauh lebih baik dari masa sebelumnya. DU banyak menunjukkan perubahan-perubahan dasar setelah diberikan intervensi, salah satunya adalah DU mulai menunjukkan keinginannya untuk menjalin komunikasi dengan perempuan. Hal tersebut sesuai dengan yang dinyatakan adler bahwasannya individu membuat alternatif persepsi serta memodifikasinya sehingga menimbulkan peningkatan dalam hubungan sosial individu (Watts, 2003).

Selain itu DU juga tampak mau turut membantu menyiapkan makan untuk rekan-rekan lain didalam bangsal, tidak lagi mendahulukan keinginannya, yang mana dimasa sebelumnya DU enggan untuk melakukannya. DU juga mulai aktif berkegiatan dirumah yang ditunjukkan dengan mengurus ayam peliharaannya dengan baik dan mau melakukan kegiatan yang sudah dijadwalkan sebelumnya. Hal ini dipandang adler bahwa individu tersebut telah mengalami kesejahteraan sebagai manusia yang ditunjukkan dengan mau turut berkontribusi sosial dan mau melakukan perubahan dalam konteks sosial (Watts, 2003). Bentuk-bentuk perubahan minat sosial menurut adler tampak seperti, keberanian untuk menjadi tidak sempurna, kontribusi untuk kesejahteraan bersama, kepercayaan diri, kepedulian, kasih sayang, kreativitas, kedekatan, kerja sama, dan komitmen (Miller \& Taylor, 2016).

Selain itu konseling ini dinilai dapat memberikan insight yang nyata kepada DU. DU yang semula enggan melakukan pekerjaan dan memilih untuk berdiam diri serta banyak tidur. Kini mulai menyadari bahwa tanpa adanya aktivitas ataupun kegiatan dapat membuat DU semakin terpuruk, dan hal tersebut semakin membuat DU jauh menuju superioritasnya. Aktivitas yang dibuat dalam tahapan intervensi ini terdiri dari aktivitas jangka pendek dan aktivitas jangka panjang. Keduanya memiliki tujuan untuk mengajarkan DU mengubah gaya hidupnya. Perubahan yang dilakukan pada pola gaya hidup DU dilakukan guna mengurangi perasaan inferior yang selama ini DU alami. DU yang merasa tidak nyaman berteman dengan anak seusianya, serta kerap mendapatkan kekerasan fisik dari orang terdekatnya membuat DU kurang mengembangkan minat sosialnya. Hal tersebut juga dinyatakan dalam hasil penelitian sebelumnya bahwa perasaan inferioritas dipengaruhi oleh perasaan yang tidak aman dan juga kesendirian (Akdo, 2017).

Berdasarkan hasil intervensi yang telah dilakukan bahwa konseling adler dapat menurunkan inferioritas pada pasien skizofrenia sehingga mampu meningkatkan minat sosial, memiliki sikap tanggung jawab, dan membantu DU dalam menemukan kreativitasnya. Hal ini sesuai hasil penelitian yang dilakukan bahwa konseling adler mampu memberikan peluang untuk mengintegrasikan kreativitas, koneksi sosial, tanggung jawab pribadi, dan holism (Ziomek-Daigle \& Land, 2016). Konseling adler merupakan intervensi yang membantu memfasilitasi wawasan yang melibatkan pandangan yang salah tentang diri sendiri, orang lain, dan dunia yang mengacu pada 
pengambilan keputusan sadar untuk merasakan dan bertindak secara berbeda. Konseling ini juga memiliki fungsi sebagai dasar yang aman bagi DU untuk menguji cara berpikir dan berperilaku baru (Miller \& Taylor, 2016).

\section{Kesimpulan}

Konseling adler mampu berperan dalam membantu pasien skizofrenia untuk menemukan insight sehingga DU dapat menyadari tentang keyakinan yang salah selama ini. Dengan menemukan insight, DU mampu memahami dan menemukan gaya hidup yang seharusnya ia terapkan. Sesi konseling adler juga memberikan kesempatan kepada DU untuk belajar ulang mengenai tatanan dirinya, sehingga DU seolah menjadi pribadi yang baru. Pemberian tugas jangka pendek dan jangka panjang diperuntukan membangun ulang kepercayaan DU terhadap kemampuan yang dimilikinya. Sehingga DU bisa hidup berdampingan dengan masyarakat tanpa perlu merasa inferior. Kemampuannya dalam menemukan insigt, membuat perubahan dalam minat sosialnya, dan juga belajar ulang menjadi pribadi yang baru mampu membawa DU dalam mengurangi perasaan inferioritasnya.

\section{Referensi}

Adler, A.(1927). Understanding human nature. Greenberg

Adler, A. (1964). Superiority and social interest: A collection of later writings. Norton

Adler, A. (1979). Superiority and social interest: A collection of later writings. H. L. Ansbacher \& R. R. Ansbacher (Eds. Norton.

Adler, A. (1998). What life could mean to you. C. Brett, Trans. Hazelden.

Adler, A., Paulin, T. \& Kapusta, N. D. (2009). Etiology and therapy of neuroses. Journal of Individual Psychology, 65 (2),103-109.

Akdo, R. (2017). A model proposal on the relationships between loneliness, insecure attachment, and inferioritas feelings. 111,19-24. https://doi.org/10.1016/j.paid.2017.01.048

Akdogan, Ramazan., Merve Aydın, \& Hazal Eken. (2018). Understanding the contribution of abnormal inferioritas feelings on insecure attachment through gender and culture. The Journal of Individual Psychology, 74 (1), 96-116. https: //doi.org/10.1353/jip.2018.0006

Akdo, R. (2017). A model proposal on the relationships between loneliness, insecure attachment, and inferiority feelings. 111,19-24. https://doi.org/10.1016/j.paid.2017.01.048

Alwisol. (2009). Psikologi kepribadian. Edisi revisi. UMM Press

American Psychiatry Association. (2013). Diagnostic and statistical manual of mental disorders. Fifth edition. American Psychiatry Association

Ansbacher, H. L., \& Ansbacher, R. R. (1964). The individual psychology of Alfred Adler: A systematic presentation in selections from his writings. Harper Perennial.
Bowlby, J. (1973). Attachment and loss: Separation, anxiety and anger. Basic Books.

Bowlby, J. (1980). Attachment and loss, Vol. 3. Basic Books.

Bowlby, J. (1984). Violence in the family as a disorder of the attachment and caregiving systems. American Journal and Psychoanalysis, 44, 9-27. http://dx.doi.org/10.1007/ BF01255416

Çalıs,ır, M. (2009). The relationship of adult attachment theory and affect regulation strategies to depression. Current Approaches in Psychiatry, 1, 240-255.

Close, E. Richard. (2015). Adlerian counseling in a virtual world: Some implications of internet practice for the development of gemeinschaftsgefiihl. The Journal of Individual Psychology, 71 (2).https://doi.org/10.1353/jip.2015.0017

Carich, A. Peter. (2001). Use of Adlerian concept in healing severe physcal and sexual abuse. The Journal of Individual Psychology, 57 (1).

Delvecchio, G., Sugranyes, G., \& Frangou, S. (2013). Evidence of diagnostic specificity in the neural correlates of facial affect processing in bipolar disorder and schizophrenia: A meta-analysis of functional imaging studies. Psychological Medicine, 43(3), 553-569. https://doi.org/10.1017/ S0033291712001432

Delvecchio, G., Sugranyes, G., \& Frangou, S. (2013). Evidence of diagnostic specificity in the neural correlates of facial affect processing in bipolar disorder and schizophrenia: A meta-analysis of functional imaging studies. Psychological Medicine, 43(3), 553-569. https://doi.org/10.1017/ S0033291712001432

Ergüner-Tekinalp, B. (2017).The effectiveness of Adlerian-Based Encouragement Group Counseling with college students in Turkey. 73(1), 54-69. https://doi.org/10.1353/jip.2017.0004

Farreny, A., Savill, M., \& Priebe, S. (2018). Correspondence between negative symptoms and potential sources of secondary negative symptoms over time. European Archives of Psychiatry and Clinical Neuroscience, 268(6), 603-609. https://doi.org/10.1007/s00406-017-0813-y

Feist, Jess., Feist, J. Gregory., \& Roberts, Ann, T. (2017). Teori kepribadian. Edisi 8. Salemba Humanika

Gladding, T. Samuel. (2019). Konseling profesi yang menyeluruh. PT. Indeks.

Lieberman, A. F., \& Van Horn, P. (2008). Psychotherapy with infants and young children: Repairing the effects of stress and trauma on early attachment. Guilford Press.

Laird, T.G., \& Shelton, A.J. (2006) From an Adlerian Perspective: Birth Order dependency and binge drinking on histrorically black University Campus. Journal of Individual Psychology, 62, 18-35.

McGurk, S. R., \& Mueser, K. T. (2004). Cognitive functioning, symptoms, and work in supported employment: A review and heuristic model. Schizophrenia Research, 70(2-3), 147-173. https://doi.org/10.1016/j.schres.2004.01.009

Miller, R., \& Taylor, D. D. (2016). Does Adlerian theory stand the test of time?. Examining Individual Psychology From a Neuroscience Perspective, 5, 111-128. https://doi.org/10. 
1002/johc. 12028

Mosak, H. H. (1989). Adlerian psychotherapy. In R. J. Corsini \& D. Wedding (Eds.), Current psychotherapies (pp. 65-118). Peacock.

Mosak, H. H., \& Maniacci, M.P. (1999). A primer of Adlerian psychology. The analytic-behavioralcognitive psychology of Alfred Adler. Brunner-Routledge.

Miller, R., \& Dillman Taylor, D. (2016). Does Adlerian theory stand the test of time?: Examining individual psychology from a neuroscience perspective. Journal of Humanistic Counseling, 55(2), 111-128. https://doi.org/10.1002/johc. 12028

Safitri, A., Niko, P. F., M.Si, S., Fitriyana, N., Erawan, H., \& Baidarus, D. (2018). Psikoedukasi eeks mengenai LGBT di SMA Muhammadiyah 1 Pekanbaru. Jurnal Pengabdian untukmu Negeri, 2(2), 129-133. https://doi.org/10.37859/ jpumri.v2i2.861

Sadock, B. J. (2015). Synopsis of Psychiatric (ed. 11 th). Walters Kluwer

Schuldberg, D., (2001). Six subclinical spectrum traits in normal creativity. Creativity Research Journal, 13(1), 5-16. https: //doi.org/10.1207/S15326934CRJ1301_2

Spielberger, C. D. (1972). Current trends in theory and research on anxiety. In C. D. Spielberger (Ed.). Anxiety: Current trends in theory and research, 1, 3-19. NewYork: Academic Press.

Tekinalp, E. B. (2017). The effectiveness of Adlerian-Based Encouragement Group Counseling with college students in Turkey. The Journal of Individual Psychology, 73(1), 54-69. https://doi.org/10.1353/jip.2017.0004
Watson, D., \& Clark, L. A. (1984). Negative affectivity: The dispositionto experience aversive emotional states. Psychological Bulletin, 96, 465-490. https://pubmed.ncbi. nlm.nih.gov/6393179/

Watson, D., \& Tellegen, A. (1985). Toward a consensual structure of mood. Psychological Bulletin, 98, 219-235. https://doi. org/10.1037/0033-2909.98.2.219

Watts, E. Richard. (2017). Adlerian and constructivist therapies: A Neo-Adlerian perspective. The Journal of Individual Psychology, 73(2), 139-155 https://doi.org/10.1353/jip.2017. 0012

Watts, R. E. (2003). Adlerian Therapy as a relational constructivist Approach. The Family Journal, 11(2), 139-147. https: //doi.org/10.1177/1066480702250169

Wilder-Willis, K. E., Shear, P. K., Steffen, J. J., \& Borkin, J. (2002). The relationship between cognitive dysfunction and coping abilities in schizophrenia. Schizophrenia Research, 55(3), 259-267. https://doi.org/10.1016/S09209964(01)00211-0

Wingett, W., \& Milliren, A. (2008). Psychoeducational E5 groups for use in schools. Journal of Individual Psychology, 64(4), 494-505. https://doi.org/10.7220/2345-024X.14.2

Zhu, X., Li, R., Kang, G., Kang, Q., Rao, W., Yang, M., ... Yu, Q. (2019). CACNA1C Polymorphism (rs2283291) Is Associated with Schizophrenia in Chinese Males: A casecontrol study. Disease Markers. https://doi.org/10.1155/ 2019/8062397

Ziomek-Daigle, J., \& Land, C. (2016). Adlerian-Based Interventions to Reduce Bullying and Interpersonal Violence in School Settings. Journal of Creativity in Mental Health, 11(3-4), 298-310. https://doi.org/10.1080/15401383.2016. 1217182 